\section{Economic and Democratic Consolidation of the Former Yugoslav Republics}

\author{
Miro Haček \\ University of Ljubljana, Slovenia \\ iD https://orcid.org/0000-0003-1339-067X
}

Political Preferences

2021, vol. 29: 5-23

journals.us.edu.pl/index.php/PP

Submitted: 23/11/2021

Accepted: 12/12/2021

DOI: 10.31261/polpre.2021.29.5-23

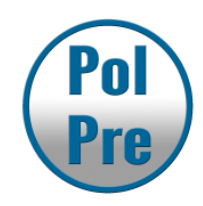

\begin{abstract}
:
Article analyses the processes of democratic consolidation in the former Yugoslav republics in the period since the volatile and violent breakup of socialist Yugoslavia three decades ago. Author is putting an emphasis on the notion of economic consolidation processes in all former Yugoslav republics and tests the thesis that economic consolidation is indeed the one prerequisite of democratic consolidation that suffered most direct effects of failed peaceful transformation in areas of former Yugoslavia that plunged into post-independence wars and conflicts. Author confirms that the secret to the democratic resilience is hidden in economic development - not only, as some theories claimed back in the 1960s (Lipset, 1959, p. 69-105), in various forms of undemocratic rule, but in a democracy built upon democratic institutions, respect for human rights and fundamental freedoms plus the rule of law.
\end{abstract}

Keywords: democracy, economy, consolidation, former Yugoslavia, republics, Slovenia.

\title{
Introduction
}

The disintegration of the socialist political system forced several countries of Central and Eastern Europe to undertake fundamental changes that were to constitute a system resembling that is present in Western societies. These states saw themselves as genuinely part of Western civilisation for they had several common historical, cultural and economic elements. Consequently, their prime development strategy was oriented to social modernisation, particularly in the sense of adopting two main institutional characteristics - a market economy and a parliamentary democracy (Tomšič 2002: 125). Before we can even discuss democratic consolidation, at least three basic conditions must be fulfilled. The first is the existence of a country because otherwise there can be no free elections or human rights. The second condition is that no democracy can be consolidated before the process of democratic transition has ended. A necessary but not a sufficient prerequisite to finish the democratic transition are free, general and democratic elections. In many cases of free, general and democratic elections it became obvious 


\section{Miro Haček}

that governments de facto lacked real decision-making power, which despite the institute of democratic elections remained in the hands of the former rulers or other powers. The third condition of democratic consolidation is therefore the necessity of democratic rule. If democratically elected authorities violate the constitution, restrict human rights, interfere with the work of other independent authorities and do not govern within the limits of the rule of law, then we cannot talk of a democratic regime. It may be concluded that only democracies can be consolidated democracies (Linz \& Stepan, 1996, p. 16). If we are to talk about a consolidated democracy, then we must also fulfil other conditions than those mentioned above. Linz and Stepan list five more interlinked prerequisites: economic consolidation, the rule of law, the existence of an organised civil society, an efficient country bureaucracy and the relative autonomy of political society (Linz \& Stepan, 1996, p. 14-33).

In this article we aim to analyse the processes of democratic transition and consolidation in the former Yugoslav republics from early 1990s, when socialist Yugoslavia finally broke apart, to the 2020, when now-independent countries celebrated their first three-decade anniversaries. We will put an emphasis on various internationally recognized measurements that try to cover a combination of elements that influence the processes of democratic transition and consolidation in the Linz and Stepan's (1996) traditional trajectory. Following their work, we will put particular emphasis on the notions of economic transition and economic consolidation processes in all former Yugoslav republics and test the assumption that economic consolidation is indeed the one prerequisite of democratic consolidation that suffered most direct effects of failed peaceful transformation in areas of former Yugoslavia that plunged into post-independence wars and conflicts.

\section{Theoretical Backgrounds}

How are the concepts of social and political modernisation to be understood? Social modernisation includes key changes in all aspects of human thought and human activities. Its elements, such as economic growth, urbanisation, development of education and establishment of the mass media are historically interlinked with the advancement of democracy. Nevertheless, establishing various democratic institutions usually lagged general progress (Zajc, 2000, p. 13). Political modernisation will, for the purposes of this article, be defined as the rationalisation of authority (dismissing various traditional, family-based, local or religious authorities and replacing 
them with secular and legitimate national authority) and the consolidation of sovereignty of the nation state versus external influences or internal regional and local powers. It further requires a division of power between legislative, juridical and executive authorities, established relations between them, and the protection of professional fields from arbitrary political influence (judiciary, armed forces and civil administration).

According to its definition and historical experience, the concept of political modernisation correlates with an increase in political independence. The right to independence and self-regulation originates from the right to mutiny against any foreign or unjust authority ('ius resistendi'). It also represents the people's right (people as a self-protecting entity) to change government, demand the government's responsibility or establish their own government (Zajc, 2000, p. 16-17). In the context of the former socialist systems, the right to mutiny and the right to self-determination enabled the formation of not only new but also more democratic states.

Despite achieving different levels of social and economic development, researchers disclosed many common characteristics of the reasons for the political modernisation seen among Central and Eastern European countries. The first of these common characteristics is a legitimacy crisis. Up until the late 1980s the monistic systems of CEE based their legitimacy entirely on ideological suppositions: of no-conflict societies; of the established belief in their 'historical right'; and of their expertise in human development. The democratic version of legitimacy proved to be more attractive to citizens, especially in socially and economically less developed countries, even more so when compared with the state's limitless and unsupervised power and the irresponsibility of its electors (Linz \& Stepan, 1996, p. 17). The second of the common characteristics is the systematic restraint of human rights. Totalitarian and authoritarian systems theoretically and practically opposed those constitutional regulations that were based on the individual and had respect for the inalienable rights of the citizens and of all the people. Particularly restricted by the authoritarian powers were the freedom of thought and freedom of expression - the pillars of an autonomous civil society. Also highly restricted was the freedom of public gathering which created circumstances fitting the monopolisation of power and the creation of an authoritarian single party system. The third of the common characteristics was the complete ineffectiveness of the socialist systems. They could not fulfil the material expectations of their citizens or solve the ever-growing problems. Socialist systems were increasingly falling behind in the race with democratic and competitive states. The fourth of the common 


\section{Miro Haček}

characteristics were the very high costs of repression. Undemocratic systems tend to break all social linkages except their own, which they form and enforce systematically. They sustain an atmosphere of uncertainty and distrust where any kind of opposition is severely sanctioned. The result of uncertainty and repressiveness is the so-called 'subculture of fear', which weakens people's ability to independently plan and act in order not to worsen their individual position. Gradually all the rights and institutions, which could ensure the success of a collective action, disintegrate. Nevertheless, in undemocratic systems there is a relationship between tolerance of political opposition and the costs of its repression. Expensive tolerance necessarily signifies an even more expensive repression. The more the costs of repression exceeded the costs of tolerance the higher became the possibility of altering the political system (Dahl, 1990).

The key reason for the political democratisation of CEE countries were the restraints on social development imposed by communist rule. In these countries the process of social development could be marked as inorganic top-down modernisation based on the idea of homogenised and disciplined society. It effectively suffocated any alternative realisation of social potential. Reforms and ideas were legal if they did not collide with the monopoly's legitimacy, based on the idea of a classless society. This was the origin of the system's incapability to ensure sustainable development, self-reproduction, the absorption of constant social changes and adjustment to the complex circumstances (Tomšič, 2002, p. 126).

The term democratic transition relates to the process of dismissing the authoritarian regime, authoritarian entities or undemocratic legislation and to the establishment of the constitutional regulation and formation of procedural rules for political competition. This process of transition from an authoritarian to a democratic system usually involves evolution. The establishment of a fully democratic system must necessarily be preceded by liberalisation - while still within the old regime's framework, certain rights must be restored or expanded to serve as protection of the individual or greater social formation, against arbitrary interventions of central powers. This enables the creation of political opposition, articulation and popularisation of new ideas and consequently also an increase in public support (Tomšič, 2002, p. 130).

The democratic consolidation requires the establishment of a suitable institutional framework. Schmitter understands consolidation as 'a process of transformation of random agreements, prudent norms and accidental decisions (formed in the period of transition) into a generally known and regularly practiced relations of cooperation and competition. These must be 
voluntarily accepted by all individuals and groups enrolled in the democratic exercise of power' (Schmitter, 1994, p. 60). To put it more simply, the process of democratic consolidation is finished when no relevant actor seeks to politically exist outside the frameworks of democratic institutions (Kukovič \& Haček 2014, p. 49) or 'when also the defeatists try to succeed only through democratic institutions' (Przeworski et al., 1996, p. 40).

\section{Measurements of Democratic Consolidation}

We can measure the success of democratic transition and democratic consolidation through various indexes. The most frequently used index is the Human Development Index (HDI), which is composed of various economical, social, demographic and other indicators. The precision and ability to determine any country's stage of development of the HDI is much greater than any other composite index or statistical indicator. HDI marks some of the fundamental achievements in a certain society, such as the average length of life, dissemination of knowledge, economic development and certain life standards. HDI is a more profound indicator than for example revenue per capita, because the latter is only one of the many means of human development but not also its result. Table 1 shows values of the HDI index from 1995 to the latest available data from 2019. Besides the actual value of the index, it also gives two kinds of information. The first one regards the stage of development a specific country has achieved, whereas the second one shows the country's position in the world ranking. The results mentioned are entirely congruent with frequently published economic indicators - Slovenia scored best among the former socialist countries in all time periods between 1995 and 2019. Between 1995 and 2019 some former Yugoslav republics advanced in their world rankings, but their progress is very diverse; Slovenia for instance moved up 15 positions, Croatia 33 and Serbia 29, but on the other hand, Montenegro stayed largely on the same level between 2010 and 2019. The case of Bosnia and Herzegovina is more troubling, as it moved down 19 positions between 2000 (when it was for the first time included in the measurement) and 2019. 
Table 1: Human Development Index (HDI)* in Central and Eastern Europe in 1995-2019

\begin{tabular}{|c|c|c|c|c|c|c|c|c|}
\hline Country & $1995^{* *}$ & 2000 & 2006 & $2010^{* *}$ & $2014^{* *}$ & $2019^{* * *}$ & $\begin{array}{l}\text { Rank } \\
1995^{* * * *}\end{array}$ & $\begin{array}{l}\text { Rank } \\
\text { 2019 }^{* * * *}\end{array}$ \\
\hline Slovenia & $\begin{array}{l}0.887 \\
\text { HD-37 }\end{array}$ & 0.884 & 0.910 & $\begin{array}{c}0.828 ; \\
\text { VHD-29 }\end{array}$ & $\begin{array}{c}0.880 \\
\text { VHD-25 }\end{array}$ & $\begin{array}{c}0.917 ; \\
\text { VHD-22 }\end{array}$ & 1. & 1. \\
\hline Croatia & $\begin{array}{l}0.759 \\
\text { MD-76 }\end{array}$ & 0.826 & 0.846 & $\begin{array}{l}0.767 \\
\text { HD-51 }\end{array}$ & $\begin{array}{c}0.818 ; \\
\text { VHD-47 }\end{array}$ & $\begin{array}{c}0.851 ; \\
\text { VHD-43 }\end{array}$ & 10. & 9. \\
\hline Romania & $\begin{array}{c}0.767 \\
\text { MD-74 }\end{array}$ & 0.773 & 0.805 & $\begin{array}{l}0.767 \\
\text { HD-50 }\end{array}$ & $\begin{array}{l}0.793 \\
\text { HD-52 }\end{array}$ & $\begin{array}{c}0.828 ; \\
\text { VHD-49 }\end{array}$ & 9. & 11. \\
\hline Bulgaria & $\begin{array}{l}0.789 \\
\text { MD-67 }\end{array}$ & 0.795 & 0.816 & $\begin{array}{l}0.743 \\
\text { HD-58 }\end{array}$ & $\begin{array}{l}0.782 \\
\text { HD-59 }\end{array}$ & $\begin{array}{c}0.816 ; \\
\text { VHD-56 }\end{array}$ & 6. & 14. \\
\hline Hungary & $\begin{array}{l}0.857 \\
\text { HD-47 }\end{array}$ & 0.843 & 0.869 & $\begin{array}{c}0.805 ; \\
\text { VHD-36 }\end{array}$ & $\begin{array}{c}0.828 ; \\
\text { VHD-44 }\end{array}$ & $\begin{array}{c}0.854 ; \\
\text { VHD-40 }\end{array}$ & 4. & 8. \\
\hline $\begin{array}{c}\text { Czech } \\
\text { Republic }\end{array}$ & $\begin{array}{c}0.884 \\
\text { HD-39 }\end{array}$ & 0.857 & 0.885 & $\begin{array}{c}0.841 ; \\
\text { VHD-28 }\end{array}$ & $\begin{array}{c}0.870 ; \\
\text { VHD-28 }\end{array}$ & $\begin{array}{c}0.900 \\
\text { VHD-27 }\end{array}$ & 2. & 2. \\
\hline Slovakia & $\begin{array}{l}0.875 \\
\text { HD-42 }\end{array}$ & 0.765 & 0.856 & $\begin{array}{c}0.818 ; \\
\text { VHD-31 }\end{array}$ & $\begin{array}{c}0.844 ; \\
\text { VHD-35 }\end{array}$ & $\begin{array}{c}0.860 ; \\
\text { VHD-39 }\end{array}$ & 3. & 7. \\
\hline Poland & $\begin{array}{l}0.851 \\
\text { HD-52 }\end{array}$ & 0.845 & 0.862 & $\begin{array}{c}0.795 \\
\text { VHD-41 }\end{array}$ & $\begin{array}{c}0.843 ; \\
\text { VHD-36 }\end{array}$ & $\begin{array}{c}0.880 \\
\text { VHD-35 }\end{array}$ & 5. & 5. \\
\hline Lithuania & $\begin{array}{l}0.750 \\
\text { MD-79 }\end{array}$ & 0.828 & 0.857 & $\begin{array}{l}0.783 ; \\
\text { HD-44 }\end{array}$ & $\begin{array}{c}0.839 \\
\text { VHD-37 }\end{array}$ & $\begin{array}{c}0.882 ; \\
\text { VHD-34 }\end{array}$ & 12. & 4. \\
\hline Latvia & $\begin{array}{l}0.704 \\
\text { MD-92 }\end{array}$ & 0.812 & 0.845 & $\begin{array}{l}0.769 \\
\text { HD-48 }\end{array}$ & $\begin{array}{c}0.819 ; \\
\text { VHD-46 }\end{array}$ & $\begin{array}{c}0.866 ; \\
\text { VHD-37 }\end{array}$ & 13. & 6. \\
\hline Estonia & $\begin{array}{l}0.758 \\
\text { MD-77 }\end{array}$ & 0.833 & 0.858 & $\begin{array}{c}0.812 ; \\
\text { VHD-34 }\end{array}$ & $\begin{array}{c}0.861 ; \\
\text { VHD-30 }\end{array}$ & $\begin{array}{c}0.892 ; \\
\text { VHD-29 }\end{array}$ & 11. & 3. \\
\hline Ukraine & $\begin{array}{c}0.665 \\
\text { MD-102 }\end{array}$ & 0.754 & 0.774 & $\begin{array}{l}0.710 \\
\text { HD-69 }\end{array}$ & $\begin{array}{l}0.747 \\
\text { HD-81 }\end{array}$ & $\begin{array}{l}0.779 \\
\text { HD-74 }\end{array}$ & 15. & 17. \\
\hline Russia & $\begin{array}{l}0.769 \\
\text { MD-72 }\end{array}$ & 0.722 & 0.797 & $\begin{array}{l}0.719 \\
\text { HD-65 }\end{array}$ & $\begin{array}{l}0.798 \\
\text { HD-50 }\end{array}$ & $\begin{array}{c}0.824 ; \\
\text { VHD-52 }\end{array}$ & 8. & 12. \\
\hline Belarus & $\begin{array}{l}0.783 \\
\text { MD-68 }\end{array}$ & 0.774 & 0.794 & $\begin{array}{l}0.732 ; \\
\text { HD-61 }\end{array}$ & $\begin{array}{l}0.798 \\
\text { HD-50 }\end{array}$ & $\begin{array}{c}0.823 ; \\
\text { VHD-53 }\end{array}$ & 7. & 13. \\
\hline Serbia & $\begin{array}{c}0.699 \\
\text { MD-93 }\end{array}$ & 0.716 & 0.754 & $\begin{array}{l}0.735 \\
\text { HD-60 }\end{array}$ & $\begin{array}{l}0.771 ; \\
\text { HD-66 }\end{array}$ & $\begin{array}{c}0.806 ; \\
\text { VHD-64 }\end{array}$ & 14. & 15. \\
\hline Montenegro & - & - & - & $\begin{array}{l}0.769 \\
\text { HD-49 }\end{array}$ & $\begin{array}{c}0.802 ; \\
\text { VHD-49 }\end{array}$ & $\begin{array}{c}0.829 ; \\
\text { VHD-48 }\end{array}$ & - & 10. \\
\hline $\begin{array}{l}\text { Bosnia and } \\
\text { Herzegovina }\end{array}$ & - & 0.679 & 0.712 & $\begin{array}{l}0.721 ; \\
\text { HD-64 }\end{array}$ & $\begin{array}{l}0.758 \\
\text { HD-77 }\end{array}$ & $\begin{array}{l}0.780 \\
\text { HD-73 }\end{array}$ & - & 16. \\
\hline
\end{tabular}

* The Human Development Index is measured on a 0 to 1 interval, where 1 represents a fully developed country and 0 represents a completely undeveloped country.

** Countries are divided into three groups: high human development (marked HD), medium human development (MD) and low human development (LD). From 2006 there was also a fourth group added, very high human development (VHD), for the most developed countries in the world. Next to this mark we placed information about the individual countries' places in the world ranking.

*** Ranking among listed former socialist countries.

Source: Human Development Report; http://hdr.undp.org/en/content/download-data (2 November 2021). 
Very similar to the Human Development Index is the Democracy Index, measured annually by an organisation called Freedom House and presented in a special report - Nations in Transit. The Democracy Index is composed of seven indicators. It includes evaluations of electoral systems, civil society, free media, democratic government at both national and local levels, independence of the judiciary, and the spread of corruption. Every indicator is measured on a scale from 1 to 7 , where 1 represents the highest level of the democratic process and 7 represents the lowest level. Nations in Transit encompasses all former socialist countries including the successor countries to the Soviet Union and Yugoslavia. All included countries are divided into five groups. The highest group includes countries with the best ratings in the Democracy Index, i.e. consolidated democracies. Countries receiving a Democracy Score of 1.00-1.99 closely embody the best policies and practices of liberal democracy, among them independent, vibrant and sustainable civil society, independent media, competitive, free and fair elections, stable, democratic, and accountable national and local government systems, etc.

From former Yugoslav republics, only Slovenia consistently ranked among consolidated democracies, mostly scoring below 2.00, but in the reports after 2016, Slovenia again crossed the threshold of 2.00; while remaining the consolidated democracy, some challenges largely associated with corruption, judiciary and independent media contributed to a slightly lower score in most recent period.

Table 2: Democracy Index in the period 1998 to 2020

\begin{tabular}{lcccccccc}
\hline & Slovenia & Croatia & $\begin{array}{c}\text { Bosnia and } \\
\text { Herzegovina }\end{array}$ & $\begin{array}{c}\text { North } \\
\text { Macedonia }\end{array}$ & Montenegro & Serbia & Kosovo & $\begin{array}{c}\text { FR } \\
\text { Yugoslavia }\end{array}$ \\
\hline $\mathbf{1 9 9 8}$ & 1.94 & 4.25 & 5.35 & 3.95 & - & - & - & 4.90 \\
$\mathbf{2 0 0 0 *}$ & 1.95 & 4.19 & 5.13 & 3.44 & - & - & - & 5.50 \\
$\mathbf{2 0 0 2 *}$ & 1.81 & 3.25 & 4.56 & 4.13 & - & - & - & 3.63 \\
$\mathbf{2 0 0 4}$ & 1.75 & 3.83 & 4.29 & 4.00 & - & - & 5.50 & - \\
$\mathbf{2 0 0 6}$ & 1.75 & 3.71 & 4.07 & 3.82 & 3.89 & 3.71 & 5.36 & - \\
$\mathbf{2 0 0 8}$ & 1.86 & 3.64 & 4.11 & 3.86 & 3.79 & 3.79 & 5.21 & - \\
$\mathbf{2 0 1 0}$ & 1.93 & 3.71 & 4.25 & 3.79 & 3.79 & 3.71 & 5.07 & - \\
$\mathbf{2 0 1 2}$ & 1.89 & 3.61 & 4.36 & 3.89 & 3.82 & 3.64 & 5.18 & - \\
$\mathbf{2 0 1 4}$ & 1.93 & 3.68 & 4.43 & 4.00 & 3.86 & 3.64 & 5.14 & - \\
$\mathbf{2 0 1 6}$ & 2.00 & 3.68 & 4.50 & 4.29 & 3.93 & 3.75 & 5.07 & - \\
$\mathbf{2 0 1 8}$ & 2.07 & 3.75 & 4.64 & 4.36 & 3.93 & 3.96 & - & - \\
$\mathbf{2 0 2 0}$ & 2.07 & 3.75 & 4.68 & 4.25 & 4.14 & 4.04 & 4.82 & - \\
\hline * Different methodology was used before 2003 in calculating democracy index, only evaluating electoral process, \\
civil society, independent media and governance. Source: Freedom House, Nations in Transit; available at \\
http://www.freedomhouse.org (2 November 2021). \\
\hline
\end{tabular}


Countries receiving a Democracy Score of 3.00-3.99 are ranked as semi-consolidated democracies. Among former Yugoslav republics Croatia, Serbia and Montenegro are being ranked among semi-consolidated democracies, but none of them sees recent positive trends that would lead toward consolidated democracy status; Serbia and Montenegro even lowered their scores to below 4.00 in the most recent report (2020). Those countries are still electoral democracies that meet relatively high standards for the selection of national leaders, but exhibit some weaknesses in their defence of political rights and civil liberties, among them irregularities that may occur during elections, widespread corruption and weak state capacities to investigate corruption, weak judicial independence and the protection of basic rights, especially those of ethnic and religious minorities, etc.

Countries receiving a Democracy Score of 4.00-4.99 are typically electoral democracies that meet only minimum standards for the selection of national leaders; those countries are either transitional or hybrid regimes. Among former Yugoslav republics, all former Yugoslav republics and Kosovo (apart from Slovenia and Croatia) are currently in this category, although some of them already ranked among semi-consolidated democracies in previous periods. Democratic institutions in those countries are fragile and face substantial challenges to the protection of political rights and civil liberties. The potential for sustainable, liberal democracy is unclear.

If we compare scores and reports from 1998 to 2020, the most noticeable characteristic is the recent regression of almost all former Yugoslav republics in terms of their democratic consolidation, most noticeably of Serbia and Montenegro in terms of reassignment to lower group. There are also few cases of progress (Kosovo in recent period, Croatia after president Tuđman's death, Bosnia and Herzegovina and North Macedonia in mid 2000s, etc.), but the differences between the grades are not substantial in most cases. We can also notice that all former Yugoslav republics apart from Slovenia received especially concerning low scores in the fields of independent media, spread of corruption and judicial framework and independence (Freedom House, 2021).

\section{The Notion of Economic Consolidation}

The process of consolidation within the economic sphere of society is only one of the conditions leading to the consolidated democracy. Even the most economically consolidated and successful society would be but a pale reflection of democracy if it lacked the institutes of civil society or the rule of law. Linz and Stepan (1996, p. 21) claim that a consolidated modern democracy requires a set of socio-political norms, institutions and arrangements in the sphere of economy - 
they term this set "economic society" - which is situated between the country and the market. Namely, democracy can be consolidated neither in the context of planned economy nor under the circumstances of a pure market economy.

We can ask ourselves why a completely free market cannot coexist with a modern consolidated democracy. In recent years, all sound studies of modern policies have empirically confirmed the existence of important degrees of country interventions into the market and country ownership in all consolidated democracies (Freeman, 1989). There are at least three arguments in support of such empirical findings and their validity. The first one stresses that, despite neoliberal claims of market's self-sufficiency, pure market economies cannot exist without a certain degree of country regulation. Namely, the market requires legislative enforcement of contracts and obligations, protection of investments and money, regulatory standards and protection of private as well as public property. Because of all this, the country must undertake certain actions in the market (Linz \& Stepan, 1996, p. 18-24). The second argument is the fact that even the most developed markets require certain corrections by the country if the market is to yield optimum performance (Murrell, 1991, p. 59-76). The last and the most important reason, which supports market intervention and country ownership in consolidated democracy, is the public character of government priorities and policies. If a democracy fails to implement policies whose direct result is the production of public goods in the domains of education, healthcare and transportation or the creation of social security networks intended to alleviate social inequalities, then democracy as such cannot exist. Therefore, were a democracy to be born in a pure market economy it would, already by its own operation, transform such an economic system from a pure market economy into a mixed-type economy or a consolidated economic sphere, i.e., something Linz and Stepan (1996, p. 18) call "economic society".

First and foremost, the consolidation of democracy requires the institutionalisation of a politically regulated market. This, in turn, demands "economic society", which, however, can only operate efficiently under the conditions of efficient country mechanisms, intended for monitoring developments in the market. A frequent objective of countries that underwent a transition into a new political and economic system in the late 1980s or early 1990s has been the project of privatisation of once socially owned business enterprises. Even such a goal, whose primary aim is to reduce the share of public property, is much easier to achieve if country mechanisms are efficient and strong enough. Economic deterioration, which is caused by the 
inability of a country to exercise its regulatory functions, significantly contributes towards the problem of economic reform and democratisation.

A modern consolidated democracy can be conceived of as a notion, which comprises five mutually, interlinked arenas, ${ }^{1}$ whereby each of them must adhere to its own organisational principle. Democracy is more than a form of rule - it is a system of mutual interaction (Przeworski et al., 1996, p. 39). None of these arenas can work properly without the support of other arenas. Hence, e.g., civil society cannot exist without the rule of law that would guarantee the citizens' rights and freedoms. Furthermore, each of these interlinked arenas exercises a certain amount of influence over others. Therefore, the arena, which is of greatest importance to our contribution, also significantly affects others and we dare say that one cannot even speak of a modern consolidated democracy without economic consolidation.

\section{Economic Indicators and the Process of Democratic Consolidation in Central and Eastern Europe}

Let us ask which factors influence a certain country at a given moment so that it will achieve and maintain the status of a consolidated democracy. This question is answered by Przeworski et al. (1996, p. 39-55) in a very large-scale project, which was presented for the first time in 1995 at a conference, entitled "Consolidating Third Wave Democracies" in Taiwan and published the following year in the Journal of Democracy magazine. The above-mentioned researchers claim that these factors are democracy, country-owned assets, economic growth with moderate inflation rates, reduction of inequalities, a favourable international atmosphere and, finally, parliamentary institutions. Their entire research project is based on data acquired in 135 countries during the period of 1950-1994. ${ }^{2}$ In this period, they identified 224 different governments, of these 101 cases of democratic rule and 123 various cases of undemocratic rule, which are not of such importance to our contribution. During the time of their research, 50 cases of transition in the direction of democracy and 40 cases of transition in the opposite direction were recorded.

In political science circles (especially in the USA) a claim has been surfacing ever since the 1950s that democracy is a cyclical phenomenon. In this context, two arguments have been made, which directly refer to economic consolidation. The first one says that various forms of undemocratic rules are more suited to achieving economic development in poorer countries; and

\footnotetext{
1 This pertains to a developed civil society, the rule of law, institutionalised economic society, an efficient and modern country bureaucracy and, finally, a relatively autonomous political society (Linz \& Stepan, 1996, p. 17).

${ }^{2}$ The year in which an individual country achieved independence or, alternatively, the year in which certain data was first available is considered as the year in which data gathering began.
} 
the second one maintains that the moment a once poor country achieves a certain degree of development, the rule of democracy gains in importance (Przeworski et al., 1996, p. 40). However, both the research project of the previously mentioned team of researchers and the results of our analysis indicate that these two theses do not withstand critical judgement. In their project, the research team thus claim that there is no basis for a greater probability of achieving higher economic growth rates under undemocratic forms of rule. ${ }^{3} 56$ countries with various forms of undemocratic regimes had less than 1,000 U.S. dollars of Gross Domestic Product (GDP) per capita at the beginning of research. ${ }^{4}$ By the project's conclusion, only eighteen of the countries had managed to pass the threshold of 1,000 U.S. dollars of GDP per capita, only six managed to exceed the limit of 2,000 U.S. dollars of GDP per capita and only three had crossed the 3,000 U.S. dollars threshold. The other 29 countries even experienced economic setbacks during that same period.

As regards the data on GDP per capita during the period of 1991-2020 (Table 3) gathered in former Yugoslav republics, it is evident that immediately after democratic change in 1991, there were numerous countries with less than 3,000 U.S. dollars of GDP per capita (Serbia, Bosnia and Herzegovina, Montenegro, North Macedonia); in latest data available (2020) there were none of the former Yugoslav republics that would still lay below the mark of 3,000 U.S. dollars of GDP per capita.

Among all six analysed former Yugoslav republics, two groups can be clearly defined according to one of the key economic indicators - GDP per capita. In the first group of countries (comprising of all the former Yugoslav republics with notable exception of Slovenia), the influence of political and economic change, which occurred during the transition into a democratic system at the end of the 1980s and the beginning of the 1990s, is reflected either in the reduction of GDP per capita during the 1991-2000 period or in painfully slow growth of GDP per capita during stated period. In some cases, GDP per capita nearly halved in the period from 1991 to 2000. In the second group of countries (Slovenia) we can record decent and steady

\footnotetext{
${ }^{3}$ For more on relationships between economic growth ant the form of political rule in Halliwell (1993).

${ }^{4}$ Gross Domestic Product (the GDP) is the most frequently mentioned and applied economic indicator, which shows the developmental phase of a certain country. Comparative analyses most often apply the GDP per capita, expressed in market prices (current prices according to the current exchange rate) or the GDP per capita, expressed in purchasing power parity. In former socialist countries, it is especially problematic to monitor the private sector, primarily as regards informal economic activities, which is therefore to a greater extent done on the basis of more or less accurate estimates provided either by central statistical offices of individual countries or by international organisations. The latter is especially characteristic of countries that were established in the territory of the former Soviet Union, therefore data from this geographical region tend to be somewhat less reliable.
} 
growths of GDP per capita also from 1991 to 2000, for instance in Slovenia GDP per capita increased by 58 percent. In the period from 2000 to 2008, the value of GDP per capita as a primary indicator of a country's economic success (Nowotny, 1997) was steadily increasing in all six countries, the most - in relative terms - in Serbia, by unbelievable 680 percent, figure indicating not only strong Serbian economic growth in stated period, but also general weakness of Serbian economy at the turn of the millennium.

The impacts of the global economic crisis can be observed when we analyse the movement of GDP per capita in the period from 2008 until 2020, and we can immediately see that impacts of the global economic crisis are very much different in different countries. The most severe impact of the crisis is clearly visible in the country with the highest nominal value of the GDP per capita in U.S. dollars, Slovenia, where the value of GDP per capita decreased 9.3 percent; much smaller decreases can also be found in the other five former Yugoslav republics. We can also clearly see that Slovenia still has by far the highest nominal value of GDP per capita in U.S. dollars in 2020, but differences are now smaller compared to two decades ago; for instance, Montenegro had only achieved 16 percent of Slovenian GDP per capita in U.S. dollars in 2000 , whereas in 2020 , the respective figure was 30.1 percent.

Table 3: GDP Per Capita at Current Prices (in USD) ${ }^{5}$ from 1991 to 2020

\begin{tabular}{ccccccccccccccccc}
\hline Country & $\mathbf{1 9 9 1}$ & $\mathbf{1 9 9 4}$ & $\mathbf{1 9 9 7}$ & $\mathbf{2 0 0 0}$ & $\mathbf{2 0 0 3}$ & $\mathbf{2 0 0 6}$ & $\mathbf{2 0 0 8}$ & $\mathbf{2 0 1 0}$ & $\mathbf{2 0 1 2}$ & $\mathbf{2 0 1 4}$ & $\mathbf{2 0 1 6}$ & $\mathbf{2 0 1 8}$ & $\mathbf{2 0 2 0}$ \\
\hline Slovenia & 6,339 & 7,231 & 10,455 & 10,201 & 14,849 & 19,673 & 27,483 & 23,510 & 22,643 & 24,215 & 21,664 & 26,104 & 25,517 \\
Croatia & 4,026 & 3,135 & 5,263 & 4,841 & 8,059 & 11,696 & 16,297 & 13,949 & 13,258 & 13,559 & 12,361 & 15,014 & 13,828 \\
$\begin{array}{c}\text { Bosnia and } \\
\text { Herzegovina }\end{array}$ & n.a. & 319 & 983 & 1,468 & 2,225 & 3,417 & 5,091 & 4,636 & 4,778 & 5,329 & 4,995 & 6,072 & 6,032 \\
$\begin{array}{c}\text { North } \\
\text { Macedonia }\end{array}$ & 2,477 & 1,794 & 1,964 & 1,854 & 2,410 & 3,326 & 4,794 & 4,545 & 4,697 & 5,468 & 5,133 & 6,087 & 5,888 \\
$\begin{array}{c}\text { Serbia } \\
\text { n.a. }\end{array}$ & n.a. & 3,380 & 915 & 3,005 & 4,383 & 7,101 & 5,735 & 6,016 & 6,600 & 5,765 & 7,252 & 7,666 \\
Montenegro & n.a. & n.a. & n.a. & 1,627 & 2,789 & 4,426 & 7,368 & 6,688 & 6,587 & 7,388 & 7,034 & 8,850 & 7,686
\end{tabular}

Source: The World Bank; available at http://data.worldbank.org/indicator/NY.GDP.PCAP.CD (1 November 2021). Note that Socialist Yugoslavia had GDP per capita at current prices 3,549 USD in 1990, with Slovenia as the strongest republic 6,950, Croatia 4,480, Serbia 3,680, Macedonia 2,230, Bosnia and Herzegovina 2,410 and Montenegro 2,620 USD per capita at current prices.

${ }^{5}$ GDP per capita is gross domestic product divided by midyear population. GDP is the sum of gross value added by all resident producers in the economy plus any product taxes and minus any subsidies not included in the value of the products. It is calculated without making deductions for depreciation of fabricated assets or for depletion and degradation of natural resources. Data are in current U.S. dollars. 
Przeworski et al. (1996, p. 39-55) further claims that it is the economic development, which importantly affects the percentage of probability of survival of a democratic rule. Democracies that are severely underdeveloped in economic terms and have a GDP per capita of less than 1,000 dollars have thus a twelve percent probability of being overthrown in the next twelve months. This percentage decreases to six percent for democracies with a GDP per capita between 1,000 and 2,000 U.S. dollars, ${ }^{6}$ to three percent for democracies with a GDP per capita ranging from 2,000 to 4,000 U.S. dollars and to one percent for democracies having a GDP per capita in the 4,000 to 6,000 U.S. dollars range.

Considering these observations and if we once again look at our data on countries created in the territory of the former Yugoslavia (Table 3) we can infer that, from the aspect of economic underdevelopment, political systems in North Macedonia and Bosnia and Herzegovina are the most compromised, as their economies still had a GDP close or even below 6,000 U.S. dollars per capita in 2020. Hereby, it needs to be stressed that the level of economic development is but one of many factors influencing the survival or demise of a democracy and that the abovementioned percentages of probability are by no means to be considered as absolute. Democracies in countries with a GDP per capita exceeding 6,000 U.S. dollars are invincible according to the level of economic development. Never has it happened so far that a democratic system would fall in a country whose GDP per capita has been higher than 6,055 U.S. dollars, ${ }^{7}$ so in this respect, all other four former Yugoslav republics can be considered perfectly safe. Thus, proceeding from the data provided by foreign researchers and those of our own research, we can conclude that the degree of economic development is an important (but, of course, far from being the only one) factor that influences the survival and consolidation of democracy. Or, if we summarize Martin Lipset, "the more a country is developed in economic terms, the greater is the probability of its democratic rule's survival" (1959, p. 69). The question why democracies tend to be more stable in economically more developed countries has been attracting extensive debates. One of the reasons also mentioned by Martin Lipset (1981, p. 27-63) stresses the fact that the intensity of distributive conflicts tends to be lesser in countries, which have achieved a higher degree of economic development.

One of the key economic indicators contributing towards democratic consolidation is the economic growth accompanied by a moderate inflation rate. Przeworski et al. (1996, p. 39-55)

${ }^{6}$ This, in other words, means that the expected lifespan of a democracy under such conditions is 17 years.

${ }^{7}$ Argentinean rate of GDP per capita in 1976 (in 1995 international dollars). 
claims that contrary to Lipset's (1981) and Olson's (1963) arguments, ${ }^{8}$ rapid economic growth ${ }^{9}$ does not contribute towards the destabilisation of democracy. According to them, only the opposite can be true: democratic rule has a greater probability of democratic consolidation and survival if annual GDP ${ }^{10}$ growth is about five percent or higher. The team of researchers further establish that negative economic growth rates are one of the most important reasons for destabilisation.

With respect to these findings, a methodological error must be emphasised, which frequently occurs in scientific literature: authors often neglect the starting and the finishing positions of countries - i.e., their situation at the beginning and the end of a research period, respectively. It is by no means possible to equate the degree of economic growth in Slovenia, which had had a stable economic growth all the way between 1991 and 2009 when negative impacts of global economic crisis hit it, with a country in which the process of democratic transition has barely begun for whatever reason. Thus, Slovenia's 4.2 percent and Bosnia and Herzegovina's 5.5 percent of annual GDP growth in 2000 can by no means be interpreted as a sign of Bosnia and Herzegovina being more successful than Slovenia, because such a piece of data also requires at least the consideration of data on growth rates for the preceding years and the data on absolute values of GDP per capita in the same year, respectively. In the selected case, a rate of 4.2 percent of annual GDP growth in Slovenia equaled 350 U.S. dollars per capita, whereas a rate of 5.5 percent of annual GDP in Bosnia and Herzegovina equaled less than 100 U.S. dollars per capita. During the period between the gaining of independence and the year 2008, only some countries (Slovenia, Bosnia and Herzegovina, Croatia etc.) were experiencing permanent and positive economic growth, whereas other countries were experiencing intensive rises and falls, which was especially the case during volatile 1990s around former Yugoslavia. Instability in all former Yugoslav republics became more distinct during the 2009-2020 period, which witnessed the negative effects of the global economic crisis and the already negative effect of Covid19 pandemic in 2020.

\footnotetext{
${ }^{8}$ In their works, these two authors warn of a greater probability that a democratic rule may become destabilised under circumstances of rapid economic growth (they define it as an annual GDP growth rate exceeding five percent).

${ }^{9}$ Rapid economic growth is also defined as exceeding a five percent annual rate of increase in GDP by the group of authors whose research we refer to.

${ }^{10}$ Average annual GDP growth rate is an important indicator of economic trends within a national economy and tells us by how much percent the GDP of a certain country increases in an observed year.
} 
Table 4: Annual GDP Growth ${ }^{11}$ in former Yugoslav republics 1994 to 2020

\begin{tabular}{|c|c|c|c|c|c|c|}
\hline Year & Slovenia & Croatia & Montenegro & $\begin{array}{c}\text { North } \\
\text { Macedonia }\end{array}$ & $\begin{array}{c}\text { Bosnia and } \\
\text { Herzegovina }\end{array}$ & Serbia \\
\hline 1994 & 5.3 & n.a. & n.a. & -1.8 & n.a. & 2.6 \\
\hline 1995 & n.a. & n.a. & n.a. & -1.1 & 20.8 & n.a. \\
\hline 1996 & 3.5 & 5.9 & n.a. & 1.2 & 89.0 & 2.4 \\
\hline 1997 & 5.1 & 6.6 & n.a. & 1.4 & 34.4 & 7.2 \\
\hline 1998 & 3.3 & 1.9 & 4.9 & 3.4 & 15.6 & 2.4 \\
\hline 1999 & 5.3 & -0.9 & -9.4 & 4.3 & 9.6 & -12.1 \\
\hline 2000 & 4.2 & 3.8 & 3.1 & 4.5 & 5.5 & 7.8 \\
\hline 2001 & 2.9 & 3.4 & 1.1 & -3.1 & 4.4 & 5.0 \\
\hline 2002 & 3.8 & 5.2 & 1.9 & 1.5 & 5.3 & 7.1 \\
\hline 2003 & 2.8 & 5.6 & 2.5 & 2.2 & 4.0 & 4.4 \\
\hline 2004 & 4.4 & 4.1 & 4.4 & 4.7 & 6.1 & 9.0 \\
\hline 2005 & 4.0 & 4.2 & 4.2 & 4.7 & 8.8 & 5.5 \\
\hline 2006 & 5.7 & 4.8 & 8.6 & 5.1 & 5.4 & 4.9 \\
\hline 2007 & 6.9 & 5.2 & 10.7 & 6.5 & 5.7 & 5.9 \\
\hline 2008 & 3.3 & 2.1 & 6.9 & 5.5 & 5.5 & 5.4 \\
\hline 2009 & -7.8 & -7.4 & -5.7 & -0.4 & -2.9 & -3.1 \\
\hline 2010 & 1.2 & -1.7 & 2.5 & 3.4 & 0.8 & 0.6 \\
\hline 2011 & 0.6 & -0.3 & 3.2 & 2.3 & 0.9 & 1.4 \\
\hline 2012 & -2.7 & -2.0 & -0.5 & -0.3 & -0.7 & -1.7 \\
\hline 2013 & -1.1 & -1.1 & 3.5 & 2.7 & 2.4 & 2.6 \\
\hline 2014 & 3.0 & -0.4 & 1.8 & 3.8 & 1.1 & -1.8 \\
\hline 2015 & 2.2 & 2.4 & 3.4 & 3.9 & 3.1 & 1.8 \\
\hline 2016 & 3.2 & 3.5 & 2.9 & 2.8 & 3.2 & 3.3 \\
\hline 2017 & 4.8 & 3.4 & 4.7 & 1.1 & 3.2 & 2.1 \\
\hline 2018 & 4.4 & 2.8 & 5.1 & 2.9 & 3.7 & 4.5 \\
\hline 2019 & 3.3 & 2.9 & 4.1 & 3.2 & 2.8 & 4.2 \\
\hline 2020 & -4.2 & -8.4 & -15.2 & -4.5 & -4.3 & -1.0 \\
\hline
\end{tabular}

Source: The World Bank, available at http://data.worldbank.org/indicator/NY.GDP.MKTP.KD.ZG/countries (1 November 2021).

Former Yugoslav republics can be divided into two groups according to the levels of GDP per capita (Table 4). First group consists of four countries that had GDP per capita in 2020 well above 6,000 USD (Slovenia, Croatia, Serbia and Montenegro). We can observe that those four countries have had quite stable GDP growth from 1994 to 2008 (with notable exceptions in

\footnotetext{
${ }^{11}$ Annual percentage growth rate of GDP at market prices based on constant local currency. Aggregates are based on constant 2,000 U.S. dollars. GDP is the sum of gross value added by all resident producers in the economy plus any product taxes and minus any subsidies not included in the value of the products. It is calculated without making deductions for depreciation of fabricated assets or for depletion and degradation of natural resources.
} 
1999), but after 2008 negative effects of the global economic crisis can be clearly seen. Also, Croatia, Serbia and Montenegro suffered quite extensive drops in GDP in the 1990s, and although there is no official World Bank data for those three countries prior to 1994, we can clearly see this if we observe drops in GDP per capita in this period. Second group of countries consists of two former Yugoslav republics that had GDP per capita close to 6,000 USD in 2020 (North Macedonia and Bosnia and Herzegovina), both of which experienced tough democratic transition in the 1990s and gross oscillations in economic growth rates. Very endemic for the former Yugoslav area is the case of Montenegrin GDP that decreased by an incredible 45 percent in 1993 relative to the year before, whereas in 1995 the GDP increased by equally astounding 40 percent over the preceding year. ${ }^{12}$ Also Montenegro has the most astounding GDP decrease in 2020 (15 percent). The data in Table 4 allows us to confirm without any reservation the interdependence of both economic indicators - the GDP per capita and annual rates of GDP growth. Slovenia, being the country with highest GDP per capita in a group, had also been achieving stable positive annual GDP per capita growth rates up until the period of global economic crisis, when also Slovenia experienced high negative GDP per capita growth rates.

Surprisingly, Przeworski et al. (1996, p. 42) found out that a moderate inflation rate has a greater contribution towards democratic consolidation than a very low rate of inflation. ${ }^{13}$ It is necessary to mention here that these findings support the hypothesis of Albert Hirschman made in 1981, who also claimed, that "a moderate inflation rate strengthens a democracy's stability" (Hirschman, 1981, p. 177-202). Data in Table 5 is allowing us to conclude that most former Yugoslav republics, except for Serbia, had managed to curb inflation by 2000. In some of the countries, inflation even decreased by over a hundred times over the 1994-2019 period. In Slovenia, the inflation rate decreased by over twenty times during that same period, falling from 21 percent in 1994 to 0.9 percent in 2009 and 1.6 percent in 2019. If our findings are compared to those of the Przeworski et al. (1996, p. 42), a conclusion can be made that none of the former Yugoslav republics have come even close to exceeding a 30-per-cent annual inflation rate after 2003, a limit that the foreign research team's research project defines as the threshold at which inflation may contribute towards the destabilisation of a democracy.

12 See World Macroeconomic Research (n.d.).

13 According to the claims made by them, even higher degrees of democratic consolidation can be expected in countries experiencing annual inflation rates between six and 30 percent than in those with annual inflation rates below six percent. 
Table 5: Annual Inflation rates in former Yugoslav republics from 1994 to 2019 (Customer Price Index; Percent $)^{14}$

\begin{tabular}{|c|c|c|c|c|c|c|c|c|c|c|c|}
\hline Country & 1994 & 1997 & 2000 & 2003 & 2006 & 2009 & 2011 & 2013 & 2015 & 2017 & 2019 \\
\hline Slovenia & 21.0 & 8.4 & 8.9 & 5.6 & 2.5 & 0.9 & 1.8 & 1.8 & -0.5 & 1.4 & 1.6 \\
\hline Croatia & 107.3 & 4.2 & 4.6 & 1.8 & 3.2 & 2.4 & 2.3 & 2.2 & -0.5 & 1.1 & 0.8 \\
\hline $\begin{array}{l}\text { Bosnia and } \\
\text { Herzegovina }\end{array}$ & n.a. & n.a. & n.a. & n.a. & 6.1 & -0.4 & 3.7 & 2.0 & -1.0 & 0.6 & 0.8 \\
\hline North Macedonia & 126.6 & 1.3 & 6.6 & 1.1 & 3.2 & -0.7 & 3.9 & 2.8 & -0.3 & 1.4 & 0.8 \\
\hline Serbia & n.a. & 23.3 & 71.1 & 9.9 & 11.7 & 8.1 & 11.1 & 7.7 & 1.4 & 3.1 & 1.8 \\
\hline Montenegro & n.a. & n.a. & n.a. & n.a. & 2.9 & 3.5 & 3.5 & 2.2 & 1.5 & 2.4 & 0.4 \\
\hline
\end{tabular}

Source: The World Bank, available at http://data.worldbank.org/indicator/FP.CPI.TOTL.ZG/countries (1 November 2021).

\section{Conclusions}

The findings provided by our short research study perfectly match those of Przeworski et al. (1996, p. 49), which emphasise the importance of economic factors in democratic consolidation. Hence, we corroborate the claims made by Martin Lipset (1981) stating that a democratic rule has better chances at consolidating in economically more successful countries. Of course, this is by no means to say that other factors, such as the setting up of democratic institutions, the rule of law, the guaranteeing of human rights and fundamental freedoms are not of key importance to democratic consolidation. Our argument refers solely to the fact that a democratic rule has a greater possibility of consolidation in an economically more successful country. It is true, though, that economic consolidation cannot be achieved without prior or at least parallel political consolidation. Democracy may even be consolidated in poor countries, yet these are faced with a need to accelerate economic development, reduce inequalities, manage inflation, not to mention the existence of democratic institutions, the guaranteeing of human rights, the rule of law, etc. The research team correctly establishes that poverty and economic stagnation are the major obstacles in the way towards democratic consolidation.

The second finding refers to the situation of democratic consolidation of the former Yugoslav republics. A democracy becomes consolidated when the rate of risk ${ }^{15}$ decreases in

\footnotetext{
${ }^{14}$ Inflation measured by the consumer price index reflects the annual percentage change in the cost to the average consumer of acquiring a basket of goods and services that may be fixed or changed at specified intervals, e.g., on a yearly basis.

${ }^{15}$ The rate of risk stands for the probability that a democratic rule will transform into some other form of rule, but with undemocratic properties. This rate is higher for countries that have only recently become democratic systems,
} 
proportion to its age (Dahl, 1990, p. 16-17). Dahl further claims that the probability of attaining democratic consolidation is greater when democracies "operate" successfully during a given time span in political, social, economic and other terms. Based on our research and other similar ones, we can confirm this claim, as one former Yugoslav republic is relatively stable and consolidated democracy (Slovenia), one is stable semi-consolidated democracy (Croatia), but the rest are transitional regimes with slightly worrisome negative democratisation trends in latest periods.

Democratic rule has a greater chance of consolidation in economically more successful countries (Przeworski et al., 1996, p. 50). After several years of economic progress, the risk rates diminish enough to allow us to speak of economic democracy. Hereby, the nominal level of GDP a country achieves is not that much important for democratic consolidation itself, as are stability, straightness and sufficient speed of economic development. Considering all this, it seems justified to claim that most former Yugoslav republics, now mostly politically consolidated or semi-consolidated democracies (or not too far from that group), are belonging to the group of economically consolidated democracies. There are few exceptions though, as some of the former Yugoslav republics still have a long and difficult path ahead of them in terms of economic consolidation, as the effects of the global economic crisis and most recent Covid19 pandemic are felt. We can conclude that the secret to the resilience of a democracy is hidden in economic development - not only, as some theories claimed back in the 1960s (Lipset, 1959, p. 69-105), in various forms of undemocratic rule, but in a democracy built upon democratic institutions, respect for human rights and fundamental freedoms and the rule of law.

\section{References:}

Dahl, A. R. (1990). Transition to Democracy. Address delivered to the symposium on "Voices of Democracy". University of Dayton, Centre for International Studies. Available at http://www.freedomhouse.com (2 November 2021).

Freedom House, Nations in Transit. (n.d.). Accessed November 2, 2021. http://www.freedomhouse.org.

Freeman, R. J. (1989). Democracies and Market: The Politics of Mixed Economies. Cornell University Press.

Halliwell, F. J. (1993). Empirical Linkages Between Democracy and Economic Growth. British Journal of Political Science, 24(2), 225-248.

Hirschman, A. (1981). The Social and Political Matrix of Inflation: Elaboration's on the Latin America. Cambridge University Press.

Huntington, S. P. (1993). The third wave: democratization in late twentieth century. University of Oklahoma Press.

for countries that can be defined as economically underdeveloped, yet with existing and operational democratic institutions, etc (Przeworski et al., 1996, 35-52). 
Human development reports. (n.d.). Accessed November 2, 2021. http://hdr.undp.org.

Kukovič, S., \& Haček, M. (2014). The processes of economic consolidation in countries of former Yugoslavia. Journal of Comparative Politics, 7(1), 36-51.

Linz, J., \& Stepan, A. (1996). Toward Consolidated Democracy. Journal of Democracy, 7(2), 14-33.

Lipset, M. (1959). Some Social Requisites of Democracy: Economic Development and Political Legitimacy. American Political Science Review, 53(1), 69-105.

Lipset, M. (1981). Political Man: The Social Bases of Politics. John Hopkins University Press.

Murrell, P. (1991). Can Neoclassical Economics Underpin the Reform of Centrally Planned Economies? Journal of Economic Perspectives, 5(4), 59-76.

Nowotny, T. (1997). Economic Transition, Democratic Consolidation and the Integration of Central Eastern European Countries into European Structures. NATO Economic Colloquium 1997.

Olson, M. (1963). The economics of the wartime shortage. Duke University Press.

Przeworski, A, Alvarez, M., Cheibub, J. A., \& Limongi. F. (1996). What makes democracies endure? Journal of Democracy, 7(1), 39-55.

Schmitter, P. C. (1994). Dangers and Dilemmas of Democracy. Journal of Democracy, 5(2), 57-74.

The World Bank. (n.d.). Accessed November 2, 2021. http://data.worldbank.org/indicator.

Tomšič, M. (2002). Politična stabilnost v novih demokracijah (Political stability in new democracies). Znanstveno in publicistično središče.

Zajc, D. (2000). Parlamentarno odločanje (Parliamentary decision-making). Faculty of social sciences, Ljubljana.

World Macroeconomic Research. (n.d.). Accessed October 31, 2021. http://kushnirs.org/macroeconomics/gdp/ gdp_bosnia_herzegovina.html\#t1. 